\title{
TRADHISI LARUNGAN BUCENG AGUNG DI TELAGA NGEBEL SEBAGAI SARANA PENARIK WISATAWAN
}

\author{
Pengembangan dari penelitian berjudul "Upacara Tradisi Larungan Wonten ing Tlaga \\ Ngebel, Kecamatan Ngebel, Kabupaten Ponorogo”.
}

Rusmawati dan Suharti

Fakultas Bahasa dan Seni Universitas Negeri Yogyakarta email: rrusma94@gmail.com

\begin{abstract}
Abstrak: Tradhisi Larungan Buceng Agung di Telaga Ngebel sebagai Sarana Penarik Wisatawan. Penelitian ini bertujuan mendeskripsikan maksud dan tujuan upacara larungan, prosesi upacara larungan, dan manfaat upacara larungan terhadap masyarakat pendukungnya. Penelitian ini menggunakan metode penelitian kualitatif. Teknik pengumpulan data dengan pengamatan berperan serta dan wawancara mendalam. Cara analisis data dengan teknik induktif. Teknik pengesahan data dengan triangulasi sumber dan triangulasi metode. Hasil penelitiannya seperti berikut. (1) Maksud dan tujuan dari upacara larungan sebagai bagian tradisi dan berkaitan dengan pariwisata. (2) Prosesi upacara larungan dibagi menjadi dua tahapan, yaitu tahap persiapan dan tahap pelaksanaan. Tahap persiapan meliputi persiapan tempat dan persiapan sesaji. Tahap pelaksanaan meliputi pembukaan, serah terima sesaji, kirab dan dilanjutkan dengan me-larung buceng agung ke tengah telaga. (3) Manfaat upacara larungan terhadap pendukungnya adalah sarana permohonan keselamatan, meramaikan pariwisata Telaga Ngebel, meningkatkan hubungan sosial diantara warga, dan meningkatkan ekonomi masyarakat.
\end{abstract}

Kata kunci: upacara tradisi, larungan buceng agung, Telaga Ngebel

Abstract: The Tradition of Larungan Buceng Agung in Ngebel Lake to Attract Tourists. This study was aimed at describing the aims and objectives of Larungan ceremony, , and the benefits to society. This study used qualitative research methods. The data collection techniques was participation observation and in-depth interviews. Then the data were analyzed using inductive techniques. The engineering validation data were using triangulation and triangulation methods. The results of this research as follows. (1) The purpose and objectives of Larungan ceremony are as part of the tradition and related to the tourism. (2) Larungan ceremonial procession is divided into two stages, namely the preparatory phase and the implementation phase. The preparation phase includes site preparation and preparation offerings. The implementation of the stage includes the opening, the handover offerings, and continued with wash out the bunceng to the middle of the lake. (3) The benefits of larungan to the communities are the means of salvation request, enliven Ngebel Lake tourism, improving social relationships between people, and improve the local economy.

Keywords: traditional ceremony, larungan buceng agung, Ngebel Lake 


\section{PENDAHULUAN}

Pariwisata saat ini menjadi suatu kebutuhan. Saat ini banyak daerah sedang membangun pariwisata baik berupa wisata budaya, wisata rohani, wisata alam, wisata edukasi, maupun jenis wisata lainnya. Aspek pariwisata ini tentunya akan berdampak pada pendapatan daerah maupun ekonomi masyarakat sekitar apabila dikembangkan dengan baik. Jawa Timur dikenal dengan banyak potensi pariwisatanya. Banyak promosi wisata sedang digencarkan oleh pemerintah, salah satu diantaranya adalah Kabupaten Ponorogo.

Kabupaten Ponorogo terletak di sebelah barat Provinsi Jawa Timur. Pada setiap tahun baru Islam atau Sura Kabupaten Ponorogo mengadakan suatu rangkaian acara berupa Grebeg Sura. Dalam acara tahunan ini ditampilkan berbagai macam seni dan tradisi seperti festival reog, pawai budaya, kirab pusaka dan larungan buceng agung yang dipusatkan di Telaga Ngebel. Adanya beberapa kegiatan ini selain untuk menjaga tradisi tentunya juga memiliki maksud lain yaitu untuk menarik wisatawan.

Upacara larungan buceng agung di Telaga Ngebel diadakan karena berhubungan dengan kepercayaan masyarakat Ngebel yakni Telaga Ngebel adalah tempat yang angker, karena setiap tahunnya sering terjadi kecelakaan di telaga sampai adanya korban jiwa, sehingga diadakan upacara larungan sampai sekarang ini. Upacara tersebut dilaksanakan sebagai sarana pencegahan kecelakaan dan sebagai sarana permintaan keselamatan terhadap Tuhan Yang Maha Esa. Selain untuk tujuan spiritual, upacara tradisi ini dilaksanakan untuk tujuan pariwisata. Diharapkan dengan adanya larungan buceng agung dapat menarik wisatawan baik dari dalam maupun luar negeri.
Upacara larungan dilaksanakan dalam dua tahapan yaitu larungan malam dan larungan pagi. Larungan malam dilakukan dengan melarung sesaji berupa buceng beras merah ke tengah telaga pada waktu tengah malam. Larungan buceng pada malam hari ini didukung oleh beberapa kegiatan diantaranya adalah tirakatan Purwo Ayu Mardi Utomo, pentas wayang, tanam syarat, dan selamatan. Larungan pagi dilakukan dengan melarung buceng agung ke tengah telaga pada waktu pagi hari. Sebelum di-larung dilakukan beberapa kegiatan diantaranya pembukaan, serah terima sesaji, kirab dan ditutup dengan di-larung-nya buceng agung sebagai puncak dari perayaan tahun baru Islam atau Sura.

Pada bulan Sura ini diyakini oleh masyarakat pendukung sebagai bulan sakral untuk memanjatkan doa, sehingga upacara larungan dilaksanakan pada bulan Sura yakni pada malam tanggal satu Sura hingga tanggal satu Sura. Upacara ini dilaksanakan dengan me-larung sesaji ke tengah telaga. Upacara larungan sendiri dalam pelaksanaannya menggunakan beraneka macam sesaji yang tentunya setiap sesaji tersebut mempunyai makna simbolik untuk mencapai tujuan-tujuan yang diharapkan. Sesaji-sesaji yang beraneka ragam tersebut menjadikan daya tarik upacara larungan, salah satu diantaranya adalah buceng agung. Dengan dilarungnya buceng agung ke Telaga Ngebel menjadikan keunikan tersendiri dari prosesi larungan, sehingga memberikan banyak dampak positif bagi masyarakat pendukungnya.

\section{METODE}

Penelitian ini menggunakan pendekatan kualitatif. Pendekatan kualitatif yang digunakan adalah deskriptif kualitatif, yaitu suatu penelitian yang 
bertujuan untuk mendeskripsikan gejala yang menjadi fokus penelitian. Data yang dihasilkan berupa kata-kata tertulis atau lisan dari orang-orang dan perilaku yang dapat diamati (Moleong, 2012: 4).

Sumber data utama dalam penelitian ini berwujud kata-kata, tindakan, maupun ubarampe-nya selebihnya adalah data tambahan seperti dokumen dan lain-lain. Sumber data dalam penelitian ini adalah informan. Informan yag dimaksud adalah para warga Kecamatan Ngebel yang mempunyai hubungan dengan upacara tradisi larungan, seperti sesepuh, juru kunci, kuncen agung, panitia serta warga masyarakat Kecamatan Ngebel. Metode yang digunakan untuk menentukan informan kunci adalah dengan "purposive sampling". Teknik pengumpulan data dengan menggunakan pengamatan berperan serta dan wawancara mendalam. Selanjutnya data dianalisis dengan menggunakan teknik analisis induktif.

Penelitian ini dilaksanakan di Kecamatan Ngebel, Kabupaten Ponorogo. Setting penelitian ini adalah upacara larungan buceng agung di Telaga Ngebel, Kecamatan Ngebel, Kabupaten Ponorogo. Setting upacara ini terdiri atas tempat di Kecamatan Ngebel, dermaga, dan sekitar telaga Ngebel, dan sesaji, kegiatan larungan pagi meliputi pembukaan, serah terima sesaji, kirab dan dilanjutkan dengan me-larung buceng agung ke tengah telaga.

\section{HASIL DAN PEMBAHASAN Maksud dan Tujuan Larungan Buceng Agung}

Larungan buceng agung dilaksanakan untuk mengakomodir dua tujuan yaitu untuk tujuan tradisi dan pariwisata. Dalam kaitanya dengan tradisi larungan buceng agung dilaksanakan sebagai sarana pencegahan kecelakaan. Dahulu sebelum dilaksanakan larungan di Telaga Ngebel sering terjadi kejadian aneh bahkan kecelakaan hingga adanya korban jiwa. Dikarenakan banyaknya kecelakaan membuat Bapak Camat Ngebel berkumpul bersama para sesepuh dan dari unsur pemerintah yakni Dikbud untuk membahas tentang terjadinya banyak kecelakaan di Telaga Ngebel dan upaya pencegahannya. Untuk itu, berdasarkan kesepakatan bersama diadakan upacara larungan di telaga Ngebel yang sekaligus dimanfaatkan sebagai daya penarik wisatawan.

Selain pencegahan kecelakaan, upacara tradisi larungan juga dimaksudkan untuk tetap menjaga pelestarian budaya Jawa sekaligus sebagai ciri khas dari Kecamatan Ngebel itu sendiri. Upacara larungan buceng agung di Telaga Ngebel diadakan setiap tahun untuk mengakomodir dua tujuan tersebut. Hal ini sejalan dengan konsep tradisi yang bertujuan untuk menciptakan kehidupan yang harmonis. Namun, hal tersebut akan terwujud apabila masyarakat menghargai, menghormati dan menjalankan suatu tradisi secara baik dan benar serta sesuai aturan.

Supaya tidak hilang kesakralanya upacara larungan dibagi menjadi dua prosesi yaitu larungan buceng beras merah malam hari dan larungan buceng agung pada pagi hari sebagai pariwisata budaya yang dilakukan oleh pejabat di wilayah Kecamatan Ngebel, dan masyarakat sekitarnya. Larungan buceng beras abang pada malam hari disebut sebagai acara inti atau acara sakral, sedangkan larungan buceng agung ini sebagai perayaan memasuki tahun baru Islam dan sudah menjadi hak pariwisata seutuhnya. 


\section{Prosesi Upacara Larungan Buceng Agung}

Prosesi upacara larungan terbagi menjadi dua, yaitu tahap persiapan dan pelaksanaan upacara. Pada tahap persiapan ini terbagi menjadi dua yaitu persiapan tempat dan persiapan sesaji.

Persiapan tempat upacara dilaksanakan pada tanggal 13 Oktober 2015. Persiapan tempat dilakukan dengan menghias dermaga dengan menggunakan berbagai macam hiasan dari janur. Hiasanhiasan tersebut di antaranya plengkung janur, kembar mayang, daun pilo, kuwade dan kladung. Selain di dermaga tempat upacara yang dipersiapkan adalah di Lapangan. Lapangan digunakan untuk kegiatan larungan pagi. Persiapan tempat di lapangan dilakukan dengan memasang tenda, membuat panggung, menata kursi, soundsystem, dan lampu.

Selain tempat upacara, pada tahap persiapan ini juga dilakukan pembuatan sesaji sebagai penunjang upacara larungan. Sesaji upacara larungan ada dua, yaitu sesaji untuk larungan malam dan sesaji untuk larungan pagi. Dalam penelitian sesaji hanya difokuskan pada sesaji larungan buceng agung. Sesaji larungan buceng dibuat oleh Bapak Priyo Hartoko yang beralamat di Dukuh Nglingi, Desa Ngebel. Sesaji yang digunakan dalam upacara larungan buceng agung seperti di bawah ini

Pertama, Buceng Agung. Selasa pagi Bapak Priyo menyiapkan ancakan untuk membuat buceng agung sekaligus mempersiapkan jodhang untuk tempat buceng agung. Ancakan dan jodhang terbuat dari bambu. Bambu yang digunakan adalah bambu wulung. Hal ini berhubungan dengan mitos bahwa salah satu penunggu telaga bernama Ki Ageng Wulung, sehingga dipercayai jodhang untuk membawa buceng agung harus bambu wulung. Bentuk dari ancakan dan jodhang seperti Gambar 1.

Pada malam harinya Bapak Priyo memasak beras merah dicampur dengan ketan. Tujuan dicampur supaya nasi yang akan ditempel pada ancakan bisa lengket. Setelah nasi matang kemudian ditempel pada ancakan hingga membentuk gunungan (Gambar 2). Buceng agung ini tingginya kurang lebih 1,7 meter. Buceng agung ini sebenarnya sama seperti malam hari, karena untuk tujuan pada larunganpariwisata dan dilihat orang banyak maka dibuat besar sehingga dinamakan buceng agung. Setelah selesai menempel nasi pada ancakan, Bapak Priyo melanjutkan dengan menghias bucengmenggunakan ingkung, buahbuahan, sayuran dan berbagai hiasan dari beraneka tanaman. Sayuran yang digunakan antara lain sawi, cabe merah, kacang panjang, dan wortel. Buahbuahan yang digunakan antara lain jambu air, nanas, jeruk, dan tomat. Hiasan buceng dari tanaman antara lain mayang, daun andong, dan daun cemara.

Bentuk buceng agung dibuat menjadi beberapa tingkatan, yaitu bagian dasar buceng, bagian bawah, bagian atas dan puncak buceng diberi sosog. Bagian dasar buceng dipasang nampan besar dan dihias dengan sawi, pisang dan wortel sebagai hiasan. Bagian bawah buceng terdiri dari beras merah yang ditempel pada ancakan. Pada bagian bawah dipasang ingkung, tomat, jambu air, wortel, daun andong,serta mayang. Bagian atas buceng dipasang kacang panjang, wortel, daun andong dan sawi. Pada bagian puncak buceng dipasang sosog untuk tempat cabe merah serta bunga hias dari plastik. Selain itu pada setiap bagian pojokan jodhang dipasang janur dengan tambahan nanas dan daun beringin yang ditata diatas janur. Buceng 
Tradisi Larungan Buceng Agung...(Rusmawati \& Suharti)

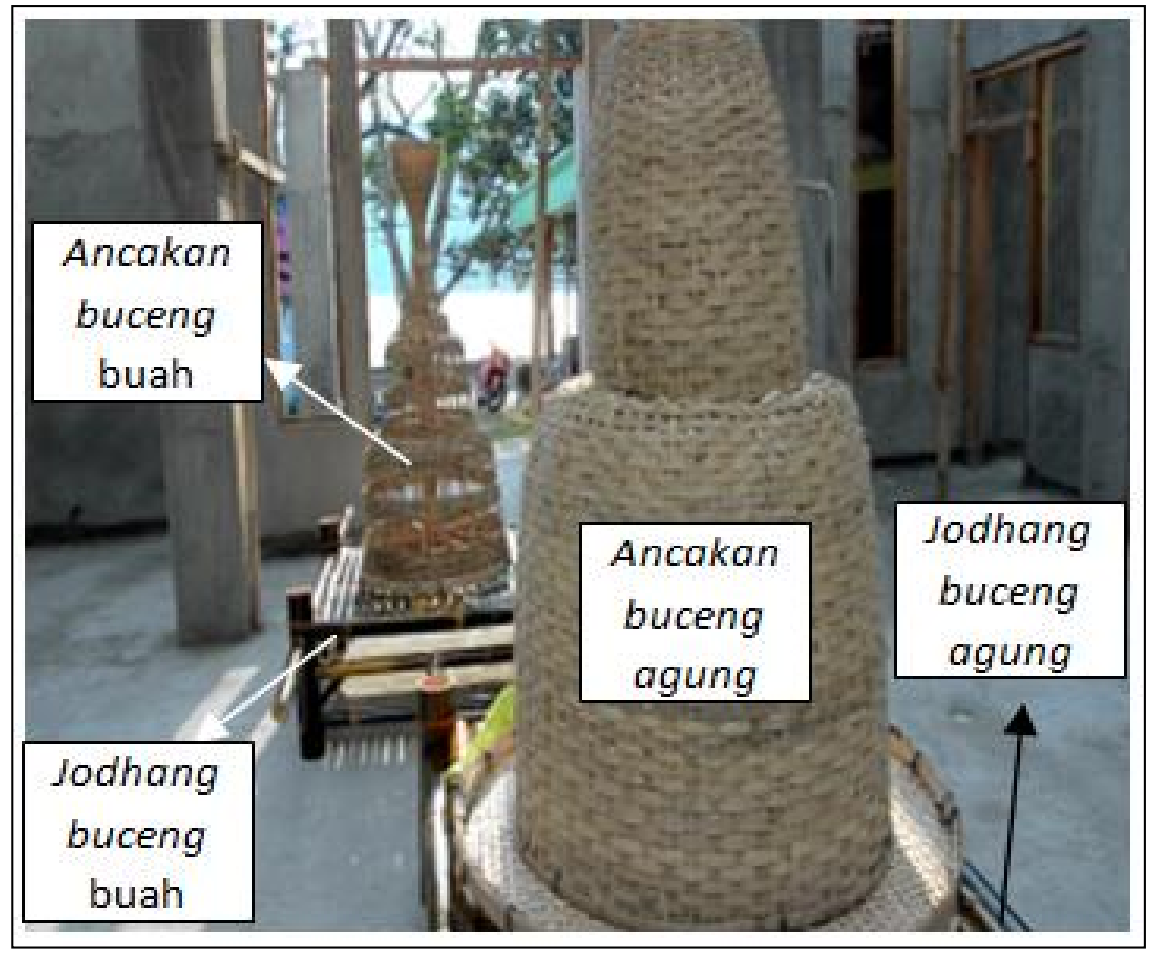

Gambar 1. Jodhang dan Ancakan

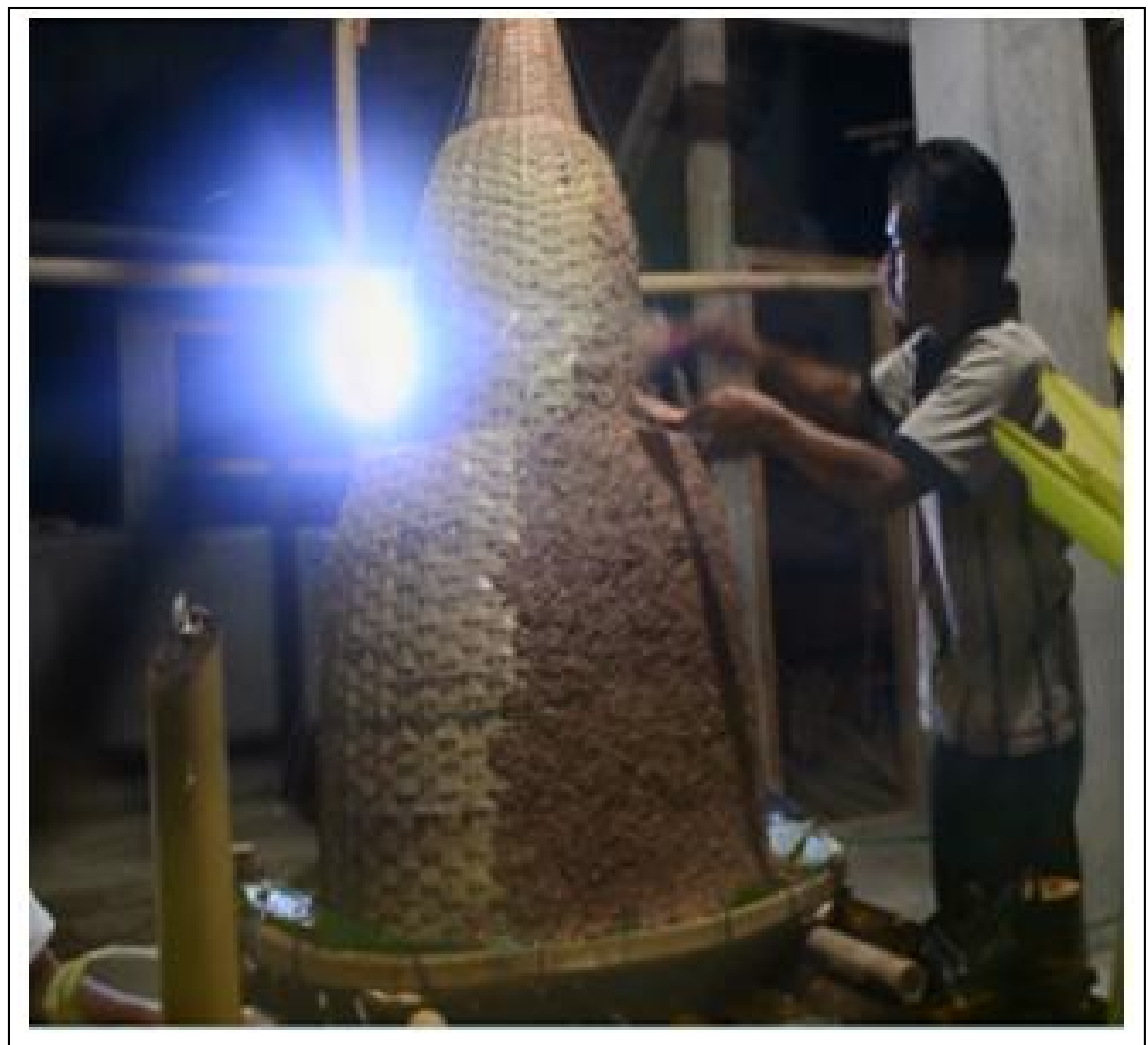

Gambar 2. Membuat Buceng Agung 
agung yang sudah dihias seperti Gambar 3.

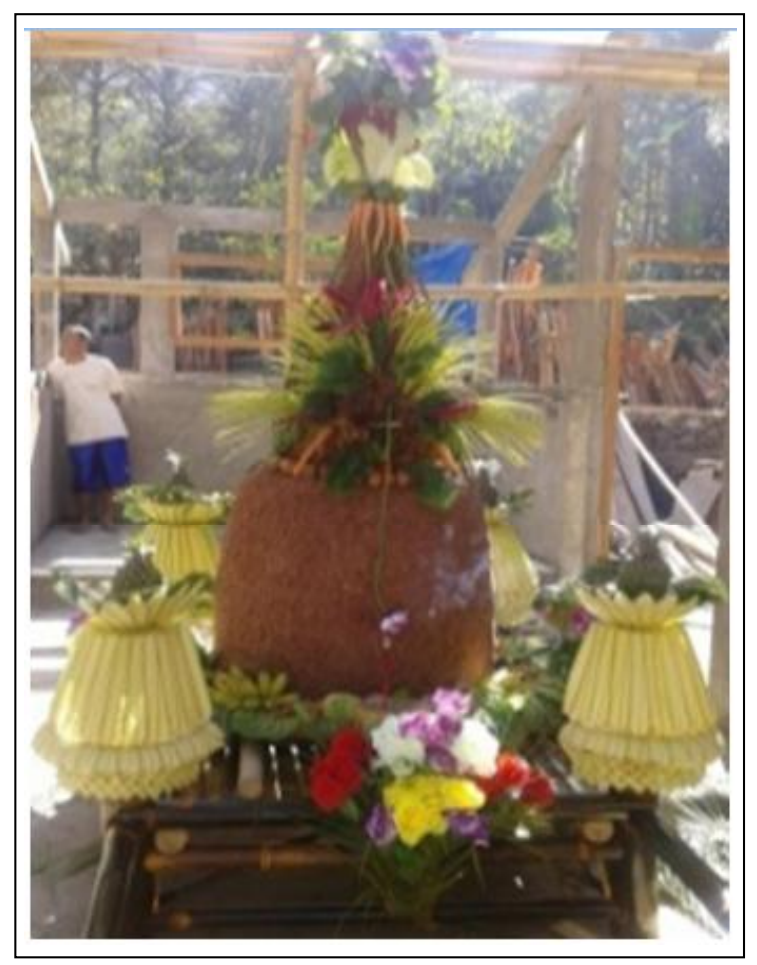

Gambar 3. Buceng Agung

Buceng agung yang digunakan dalam larungan tentunya mempunyai simbol atau filosofi. Kebudayan manusia berupa simbol, sehingga budaya manusia diwarnai dengan simbolisme, yakni pola pikir atau paham yang menjadi dasar diri terhadap simbol atau lambang (Endraswara, 2006: 172). Buceng agung ini nantinya akan dilarung ke tengah telaga sebagai ungkapan syukur warga pendukung dan sebagai sarana memohon keselamatan kepada Tuhan Yang Maha Esa. Dipakainya beras merah mengandung filosofi dimana warna merah melambangkan keberanian. Berani yang dimaksud adalah berani menghadapi cobaan apa saja.

Kedua, Buceng Buah. Sama seperti buceng agung, pada hari Selasa pagi Bapak Priyo menyiapkan ancakan sebagai tempat untuk menempel isi sesaji serta menyiapkan jodhang sebagai tempat sesaji. Ancakan dan jodhang ini terbuat dari bambu wulung. Pada malam harinya ancakan ditempel dengan buah-buahan dan sayuran (Gambar 4). Buah-buahan yang digunakan antara lain mangga, apel, pepino, kakao, nanas, semangka, pisang, jambu monyet, tomat dan belimbing. Sayuran yang digunakan untuk isi buceng antara lain terong, petai, dan bawang. Selain buah dan sayur buceng buah dihias dengan daun cemara, janur dan bunga hias.

Buceng buah dibuat menjadi dua bagian yaitu bagian bawah dan bagian atas. Pada bagian atas dipasang sosog yang dipasang bolak balik. Bagian bawah terdiri dari beberapa larik. Larik bawah ditata petai hingga mengelilingi ancakan. Larik atasnya ditata kakao, pepino dan apel. Larik berikutnya ditata terong, pisang, jambu monyet, mangga dan belimbing. Pada larik atas dipasang bawang. Sedangkan pada bagian atas yang

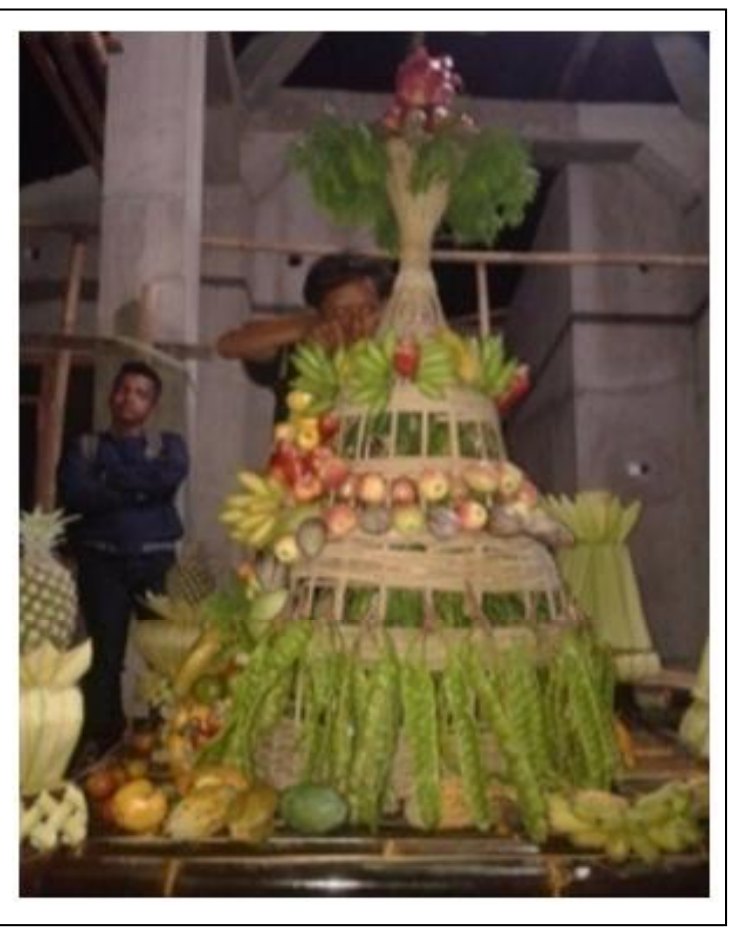

Gambar 4. Membuat Buceng Buah 
sudah dipasang sosog bolak balik dipasang semangka ,buah naga serta daun cemara. Di setiap pojok jodhang dipasang janur dengan tambahan tomat dan wortel diatas janur. Buceng buah yang sudah dihias seperti Gambar 5.

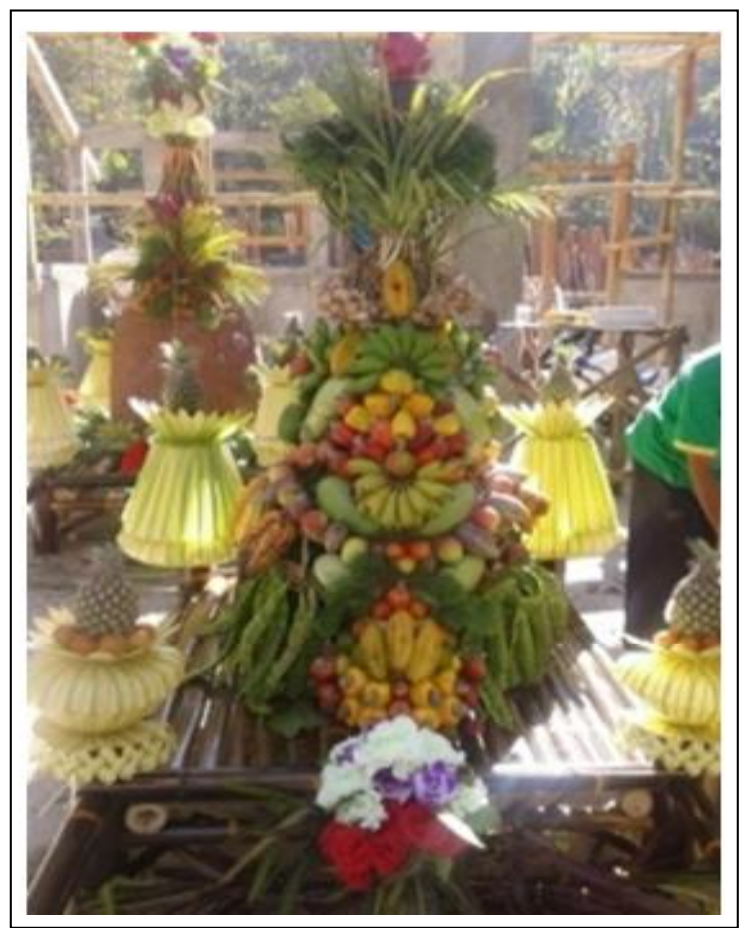

Gambar 5. Buceng Buah

Sebenarnya buah dan sayuran yang digunakan untuk buceng buah mempunyai korelasi kewilayahan, dimana Kecamatan Ngebel sendiri terletak pada dataran tinggi sehingga banyak buah dan sayur yang panen pada saat-saat tertentu. Buah dan sayur yang pasti ada untuk isi buceng buah adalah pisang, jambu mete dan petai. Pada larungan buceng agung, buceng buah tidak di-larung tetapi akan direbut atau dirayah oleh masyarakat yang datang ke Telaga Ngebel. Buceng buah ini sebagai simbol kemakmuran hasil pertanian warga Ngebel. Selain itu buceng buah menunjukkan rasa syukur kepada Tuhan yang telah memberikan hasil panen yang melimpah. Masyarakat mempercayai dengan mendapatkan bagian dari buceng buah akan mendapatkan berkah dari Tuhan Yang Maha Esa.

Larungan buceng agung dilaksanakan pada hari Rabu tanggal 14 Oktober 2015. Pagi hari sebelum dimulainya upacara para panitia dan paraga mempersiapkan sesaji buceng agung dan buceng buah yang sudah dibuat pada malam harinya dibawa menuju Pendapa Kecamatan Ngebel untuk diistirahatkan sebentar sembari menunggu datangnya rombongan bupati (Gambar 6).

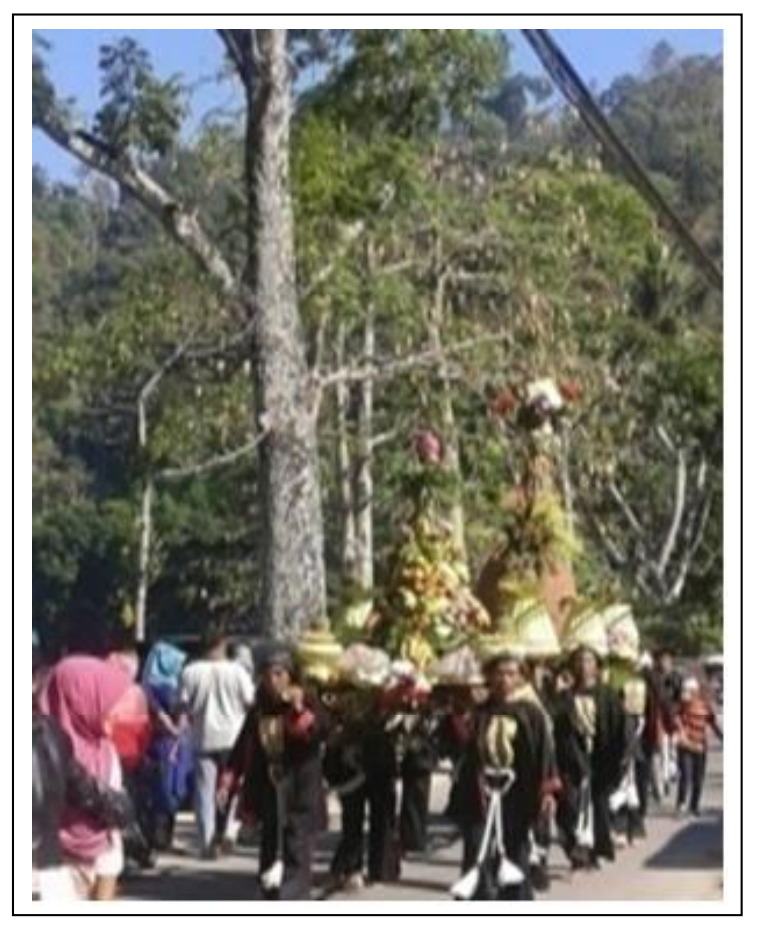

Gambar 6. Buceng Agung dan Buah

Dibawa menuju Pendapa Kecamatan

Pada pukul 09.00 WIB rombongan bupati beserta tamu undangan memasuki tempat upacara. Para panitia menyambut datangnya bupati dengan tarian gambyong yang dibawakan oleh delapan remaja putri. Setelah Tari Gambyong selesai dibawakan, 
rombongan pembawa sesaji memasuki tempat upacara. Rombongan pembawa sesaji tersebut berjalan dari kecamatan menuju tempat upacara (Gambar 7). Formasi rombongan adalah barisan paling depan adalah subamanggala atau pemimpin rombongan. Dibelakang subamanggala adalah pengapit yaitu juru kunci telaga ngebel dan sesepuh setempat. Dibelakang pengapit adalah barisan penari bedhaya, pager ayu dan pager bagus. Barisan selanjutnya adalah pembawa buceng agung dan buceng buah. Sedangkan barisan paling belakang adalah pengiring rombongan. Jalannya paraga upacara ini diiringi dengan panyandra oleh Bapak Slamet.

Dalam serah terima sesaji ini ada beberapa acara, yaitu diawali dengan pembukaan oleh Humas Protokoler Pemkab Ponorogo, dilanjutkan dengan laporan ketua panitia, sambutan bupati, serah terima sesaji dari subamanggala kepada bupati dilanjutkan dengan doa dan tari bedhaya (Gambar 8).

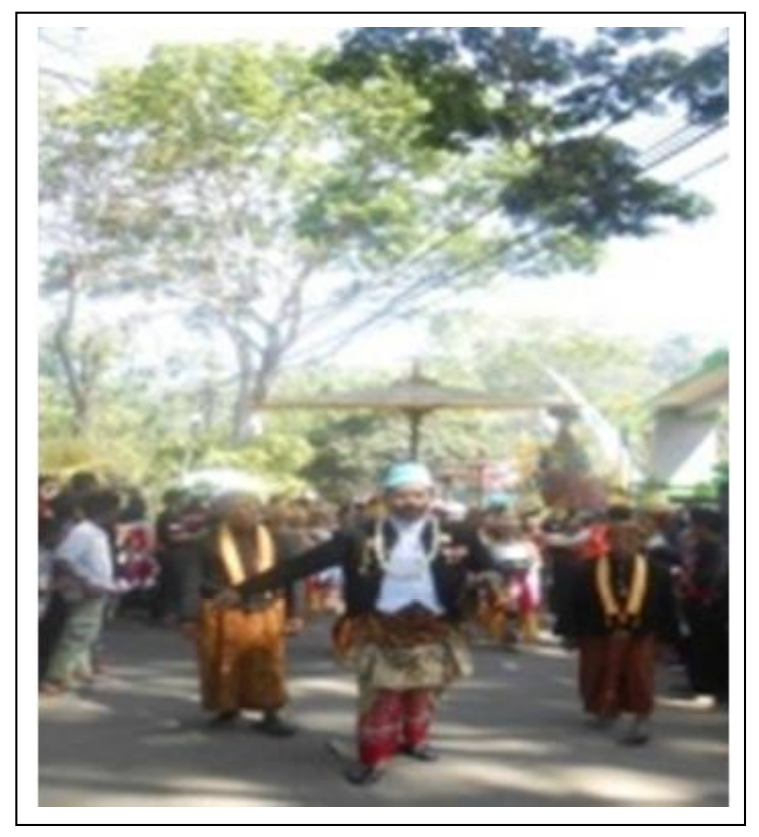

Gambar 7. Rombongan Pembawa Sesaji Memasuki Tempat Upacara

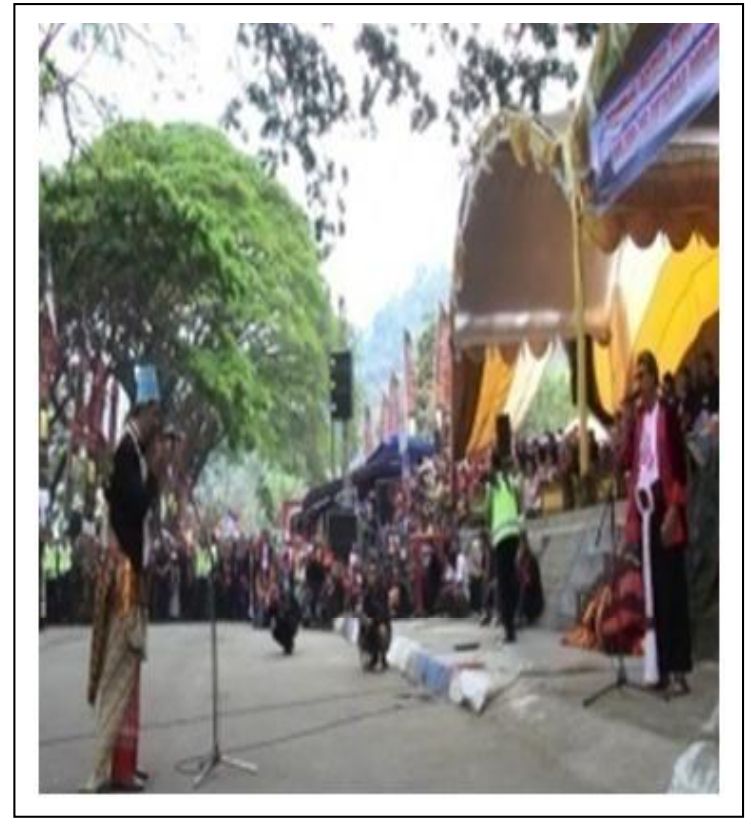

Gambar 8. Serah Terima Sesaji

Kirab dilaksanakan setelah serah terima sesaji selesai. Semua paraga dan sesaji larungan dibawa masuk kedalam mobil pick up yang sudah disedia-kan oleh panitia. Setelah semuanya siap dilanjutkan kirab keliling telaga. Tujuan kirab untuk memperingati tahun baru 1 Sura, selain itu supaya para masyarakat dapat melihat wujud sesaji larungan, yaitu buceng agung dan buceng buah. Setelah kirab selesai semua sesaji dikeluarkan dari mobil. Buceng buah diperebutkan oleh masyarakat sedangkan buceng agung dibawa ke telaga (Gambar 9).

Puncak kegiatan larungan pagi adalah me-larung buceng agung ke tengah telaga. Buceng agung yang akan di-larung terlebih dahulu ditata di atas rakit yang terbuat dari bambu. Bambu yang digunakan adalah bambu wulung.

Di pinggir telaga ribuan masyarakat sangat antusias menyaksikan prosesi dilarung-nya buceng agung. Setelah semua persiapan selesai buceng agung di-larung oleh Bapak Sagun dengan cara mendorong 
rakit hingga ke tengah telaga (Gambar 10). Dengan di-larung-nya buceng agung menandai berakhirnya acara larungan.

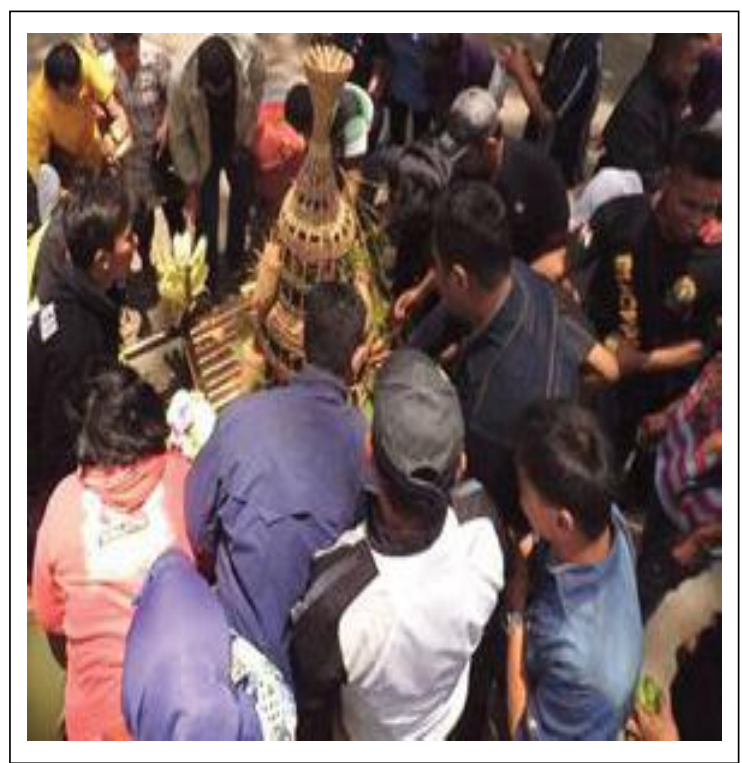

Gambar 9. Warga Memperebutkan Buceng Buah

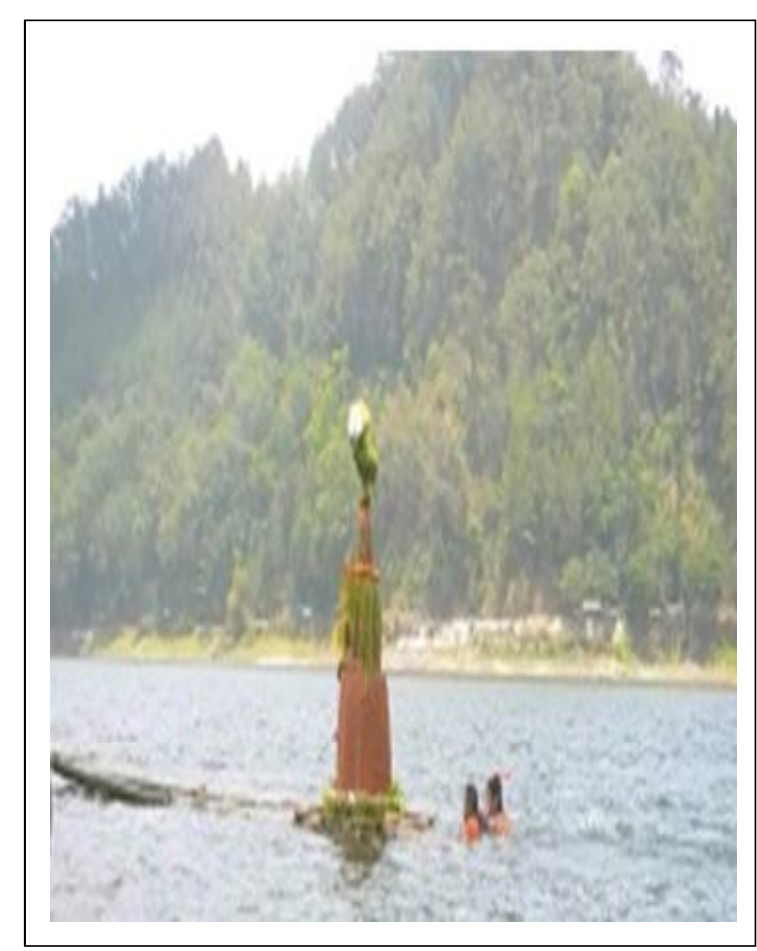

Gambar 10. Larungan Buceng Agung

\section{Manfaat Larungan Buceng Agung}

Sarana memohon keselamatan. Manfaat upacara larungan yang utama adalah sebagai sarana memohon keselamatan dengan cara berdoa bersama-sama. Dengan di-larung-nya buceng agung ke telaga diyakini oleh masyarakat pendukungnya supaya penunggu telaga tidak meminta korban sehingga dapat dikatakan sebagai pencegahan kecelakaan. Larungan buceng agung ini membuktikan bahwa upacara tradisi merupakan kegiatan sosial yang melibatkan semua warga untuk mendapatkan keselamatan.

Meramaikan pariwisata Telaga Ngebel. Telaga Ngebel yang terletak pada ketinggian 734 meter dengan suhu dingin khas dataran tinggi membuat tempat ini menjadi salah satu wisata alam andalan Kabupaten Ponorogo. Telaga ini biasanya ramai pada akhir pekan ataupun hari libur. Selain untuk memancing, para pengunjung Telaga Ngebel dapat menikmati keindahan telaga dengan wahana sepeda air maupun perahu boat. Dengan adanya larungan buceng agung ini tentunya banyak wisatawan yang datang baik dari dalam maupun luar negeri. Selain menikmati wisata alam pengunjung dapat menikmati wisata budaya yang sudah menjadi agenda tahunan Pemerintah Kabupaten Ponorogo ini. Hal ini dapat dilihat dari banyaknya karcis masuk yang terjual mencapai ratusan ribu. Untuk harga satu tiket masuk pada saat larungan adalah Rp. 20.000, sedangkan pada hari libur atau hari biasa tiket masuk adalah Rp. 5.000.

Meningkatkan hubungan sosial di antara warga. Dengan adanya larungan buceng agung, dimulai dari persiapan hingga pelaksanaan upacara tentunya tidak terlepas dari gotong royong di antara warga pendukung. Selain itu, adanya upacara larungan yang didukung oleh semua unsur pemerintahan dapat 
dijadikan sebagai sarana untuk bertemu dan berinteraksi.

Meningkatkan ekonomi masyarakat. Salah satu dampak positif yang bisa dirasakan oleh masyarakat adalah pada bidang ekonomi. Dengan banyaknya wisatawan yang datang ke Telaga Ngebel usaha masyarakat disekitar telaga seperti tempat penginapan, warung makan, maupun pedagang-pedagang lainya turut mencari berkah dengan cara berjualan. Selain pada bidang usaha, salah satu yang turut berdampak adalah pada bidang jasa seperti parkir kendaraan bermotor, pengelola sepeda air maupun kapal boat juga mendapatkan peningkatan penghasilan. Jadi secara tidak langsung adanya larungan buceng agung ini turut meningkatkan ekonomi masyarakat.

\section{SIMPULAN}

Upacara larungan buceng agung dilaksanakan dengan tujuan untuk tradisi dan pariwisata. Diharapkan dengan adanya larungan buceng agung dapat menarik wisatawan untuk datang ke Telaga Ngebel. Tentunya dengan banyaknya wisatawan yang datang akan memberikan banyak dampak positif pada bidang pariwisata dan ekonomi. Prosesi upacara larungan terbagi menjadi dua tahapan, yaitu tahap persiapan dan tahap pelaksanaan. Tahap persiapan meliputi persiapan tempat dan sesaji yaitu berupa buceng agung dan buceng buah. Pada tahap pelaksanaan larunganbuceng agung dimulai pembukaan, serah terima sesaji, kirab dilajutkan dengan me-larung buceng agung ke tengah telaga. Manfaat larungan buceng agung diantaranya sebagai sarana memohon keselamatan, meramaikan pariwisata Telaga Ngebel, meningkatkan hubungan sosial di antara warga serta berdampak pada ekonomi masyarakat.

\section{DAFTAR PUSTAKA}

Endraswara, S. 2006. Metodologi Penelitian Kebudayaan. Yogyakarta: Gajah Mada University Press.

Moleong, L. J. 2012. Metodologi Penelitian Kualitatif. Bandung: PT remaja Rosdakarya. 